\title{
Nilai persatuan dan kesatuan dalam keragaman suku bangsa
}

\author{
Alfara Derista Felany \\ Institut IImu Kesehatan Strada Indonesia
}

alfaraderista05@gmail.com

\begin{abstract}
Abstrak
Sebagai puncak keinginan pemuda untuk membentuk persatuan yang bersifat nasional yaitu Sumpah Pemuda 28 Oktober 1928. Sumpah Pemuda yang diputuskan dalam Kongres Pemuda II, 28 Oktober 1928,mempunyai arti yang penting dalam perkembangan bangsa Indonesia. Semangat persatuan yang dikumandangkan bersama berhasil mengatasi prasangka suku, golongan, dan budaya. Sumpah Pemuda menjiwai perjuangan nasional selanjutnya dan kehidupan bangsa Indonesia sesudah mencapai kemerdekaan.

Nilai-nilai budaya tentang persatuan dan kesatuan sebenarnya telah dimiliki dan dijunjung tinggi oleh masing-masing sukubangsa di Indonesia. Nilai-nilai tersebut antara lain: 1) Nilai yang terkait pada ajaran desa mawa cara negara mawa tata; 2) Nilai yang terkait pada ajaran kiwa tengen mula matunggalan; 3) Nilai toleransi; 4) Nilai menjunjung tinggi masyarakat dan kegotongroyongan; 5) Nilai kesetiakawanan dan 6) nilai tenggang rasa. Apabila nilai-nilai tersebut betul-betul bisa dilaksanakan maka kedamaian dan ketenteraman akan terwujud di Indonesia. 'Bhinneka Tunggal Ika' bukan hanya sebagai semboyan saja, tetapi merupakan pengikat negara Republik Indonesia yang terdiri dari beribu-ribu pulau besar dan kecil serta dihuni beratus-ratus suku bangsa.
\end{abstract}

\section{Latar Belakang}

Bangsa Indonesia dikenal sebagai bangsa majemuk, ditandai dengan banyaknya etnis, suku, agama, budaya, kebiasaan, di dalamnya. Di sisi lain, masyarakat Indonesia dikenal sebagai masyarakat multikultural, masyarakat yang anggotanya memiliki latar belakang budaya (cultural background) beragam. Kutipan Putusan Kongres Pemuda Pemudi Indonesian pada tanggal 28 Oktober 1928 tersebut di atas, pada hakekatnya merupakan pernyataan integrasi bangsa yang dilakukan oleh berbagai organisasi pemuda pada masa lalu. Adapun organisasi pemuda tersebut yakni Jong Java, Jong Sumatranen Bond (Pemuda Sumatera), Pemuda Indonesia, Sekar Rukun, Jong Islamieten Bond (Pemuda Islam), Jong Celebes, Jong Batak, Pemuda Betawi, dan Perhimpunan Pelajar-Pelajar Indonesia. 2 Keputusan Kongres Pemuda Tahun 1928 tersbut merupakan tonggak sejarah yang sangat penting dan telah mengajarkan pada kita, bahwa mendahulukan kesukuan dan kedaerahan dari pada kepentingan nasional dan persatuan adalah suatu tindakan yang sia-sia. Terbukti bahwa dalam berbagai perjuangan yang dilakukan oleh bangsa kita secara kedaerahan tanpa persatuan senantiasa gagal dan 
mendatangkan kesengsaraan. Sehingga kita dijajah oleh bangsa Belanda, Portugal, Inggris dan bangsa Jepang. Sungguh suatu penderitaan yang sangat pahit dan menyedihkan. Oleh karena itu 'ikrar' atau 'Sumpah Pemuda' yang diputuskan dalam Kongres Pemuda, 28 Oktober 1928 oleh organisasi- organisasi pemuda adalah sangat tepat dan strategis dalam memperkokoh persatuan dan kesatuan untuk melawan penjajah. Akhirnya dengan mengkristalnya persatuan dan kesatuan bangsa, kemerdekaan dapat direbut dari penjajah Jepang dan berkumandanglah Proklamasi Kemerdekaan pada tanggal 17 Agustus 1945 yang diproklamasikan oleh Soekarno - Hatta. Sementara itu dalam rangka memelihara persatuan dan kesatuan bangsa pembukaan Undang Undang Dasar 1945 telah menegaskan bahwa melindungi segenap bangsa Indonesia dan seluruh tumpah darah Indonesia dengan berdasar atas persatuan dengan mewujudkan keadilan sosial bagi seluruh rakyat Indonesia. Pernyataan tersebut menegaskan bahwa negara telah menghindari segala paham golongan dan menghindari segala paham perseorangan yang dapat memecah belah negara. Prinsip persatuan adalah di atas segalanya. Kondisi ini adalah merupakan suatu nilai dasar yang telah disepakati oleh bangsa Indonesia sejak dari awal. Kebangsaan yang kita bangun tidak tegak di atas landasan dan kepentingan suku bangsa, agama, ras, dan ikatan-ikatan primordial, melainkan persatuan nasional itu kita bangun dan tegakkan justru di atas landasan suku bangsa berangkat dari kesadaran untuk memperbaiki nasib sebagai satu bangsa.

\section{Kasus / masalah}

1) Bagaimana nilai - nilai persatuan dan kesatuan di kembangkan agar integrasi nasional dapat terwujud?

2) Apa saja permasalahan yang sering menghambat integrasi nasional yang disebabkan ketertutupan sukubangsa?

\section{Tinjauan Pustaka}

Persatuan / Kesatuan: Persatuan/kesatuan berasal dari kata satu yang berarti utuh atau tidak terpecah-belah. Persatuan/kesatuan mengandung arti "bersatunya macam-macam corak yang beraneka ragam menjadi satu kebulatan yang utuh dan serasi." Indonesia: Mengandung dua pengertian, yaitu pengertian Indonesia ditinjau dari segi geografis dan dari segi bangsa. Dari segi geografis, Indonesia berarti bagian bumi yang membentang dari $95^{\circ}$ sampai $141^{\circ}$ Bujur Timur dan $6^{\circ}$ Lintang Utara sampai 110 Lintang Selatan atau wilayah yang terbentang dari Sabang sampai Merauke. Indonesia dalam arti luas adalah seluruh rakyat yang merasa senasib dan sepenanggungan yang bermukim di dalam wilayah itu. Persatuan dan kesatuan Bangsa Indonesia berarti persatuan bangsa yang mendiami wilayah Indonesia. Persatuan itu didorong untuk mencapai kehidupan yang bebas dalam wadah negara yang merdeka dan berdaulat. 
Kedudukan Warga Negara Indonesia telah diatur sesuai hak dan kewajiban yang tercantum dalam pasal-pasal UUD 1945 seperti Pasal 27, Ayat 1 yang berbunyi: 'Segala warga negara bersamaan kedudukannya di dalam hukum dan pemerintahan dengan tidak ada kecualinya'

Di samping itu hak warga negara dalam mendapat pekerjaan telah dijelaskan dengan tegas tanpa membedakan dari golongan mana, seperti tercakup dalam pasal 27 Ayat 2 yang berbunyi: ' Tiap warga negara berhak atas pekerjaan dan penghidupan yang layak'. Sedang hak memeluk agama sesuai keyakinan tercakup dalam Pasal 29, Ayat 2, dan hak memperoleh pendidikan tercakup dalam Pasal 31, Ayat 2. Dari kenyataan tersebut, jelaslah bahwa negara sama sekali tidak membedakan antara satu warga dengan warga lainnya. Semua warga negara mempunyai hak yang sama. Akan tetapi di samping hak tersebut tentunya kita mempunyai tanggung jawab terhadap kewajiban, yaitu untuk mempertahankan negara seperti tercantum pada UUD 1945 Pasal 30, Ayat 1. Pembelaan di sini bukan berarti dalam pengertian sempit hanya semata-mata terhadap serangan musuh, tetapi dalam pengertian yang lebih luas yaitu memelihara negara dengan menjaga keserasian dan keselarasan hidup di masyarakat dengan aneka ragam suku bangsa, agama, ras dan budaya.

\section{Pembahasan}

1) Nilai - nilai persatuan dan kesatuan di kembangkan agar integrasi nasional dapat terwujud.

Nilai-nilai budaya asli tentang persatuan dan kesatuan sebenarnya telah dimiliki dan dijunjung tinggi oleh masing-masing suku bangsa di Indonesia. Kondisi seperti ini dibuktikan dengan keadaan yang damai, tenteram dan hubungan yang harmonis di antara sukubangsa pada masa lalu. Keadaan baru berubah, ketika penjajah datang di bumi nusantara ini. Nilai-nilai kerukunan, persatuan dan kesatuan cenderung dikaburkan agar bangsa Indonesia terpecah belah, lemah dan mudah dijajah. Politik yang sangat terkenal yang digunakan penjajah adalah 'Politik De Vide et Impera'. Akibatnya berbagai ajaranyang mengandung nilai-nilai persatuan dan kesatuan yang dimiliki oleh sukubangsa yang ada di Indonesia merupakan barang langka dan kurang dikenal oleh generasi muda khususnya dan masyarakat pada umumnya. Oleh karena itu nilai-nilai persatuan dan kesatuan perlu terus digali, dikembangkan, dan disosialisasikan agar integrasi nasional dapat diwujudkan. Adapun nilai-nilai itu antara lain:

1. Nilai yang terkait pada ajaran 'Desa mawa cara negara mawa tata'.

Ajaran ini terdapat pada sukubangsa Jawa yang mengandung petunjuk bagi kearifan pola hubungan antara suku bangsa maupun antar wilayah atau negara, dengan kesadaran bahwa orang dari daerah masing-masing mempunyai adat kebiasaan dan kebudayaan yang berbeda. Kesadaran akan adanya nilai yang berbeda tersebut menyebabkan setiap orang Jawa telah mempunyai pedoman dalam berinteraksi dengan orang di luar sukubangsa untuk tidak saling menyinggung perasaan atau saling menyakiti. Oleh sebab itu hubungan dibuat agar harmonis dengan melalui unggah-ungguh atau subasita atau tata krama dalam berhadapan dengan orang lain baik sesama sukubangsa, maupun antara atasan dengan bawahan atau 
orang tua dengan yang lebih muda. Semua itu diarahkan pada suasana selaras dan serasi yang digambarkan pada semboyan 'Leladi sesameng dumadi memayu hayuning sesami' yang berarti mengabdikan diri kepada masyarakat guna mencapai kebahagiaan sesama hidup.

2. Pada suku bangsa Bali terdapat sebuah ungkapan yang mengandung nilai persatuan yakni 'kiwa tengen mula matunggalan' (kiri kanan memang bersatu).

'Kiwa' dikiaskan dengan golongan lemah, dan dimaksudkan kaum wanita sedangkan kata 'tengen' adalah golongan kuat, maksudnya adalah kaum pria. Oleh karena itu untuk mencapai suatu hasil yang baik atau yang dicita- citakan maka kaum yang lemah dan kuat harus dipersatukan atau yang dicita- citakan maka kaum yang lemah dan kuat harus dipersatukan atau dapat bekerja-sama. Dalam ungkapan tersebut terkandung nilai pentingnya persatuan antar kelompok mayoritas dan minoritas atau antar kelompok lemah dan kelompok kuat, meliputi antar sukubangsa, antar agama, kaya dan miskin dan lain sebagainya, agar dapat mencapai suatu kondisi yang ideal dalam masyarakat. Adanya nilainilai persatuan ini juga didasari akan pengetahuan bahwa setiap daerah itu mempunyai adat istiadat sendiri. Hal ini terdapat dalam ungkapan yakni 'len tongosno len suksesmanne'. Maksudnya adanya pengakuan terhadap budaya orang lain, sehingga menyebabkan masyarakat Bali cepat beradaptasi dengan orang lain, yang tidak satu suku ataupun satu paham demi integrasinya hubungan yang baik. Bervariasinya segala kekuatan yang ada didasari bahwa bila dipersatukan akan mendapatkan kekuatan yang tinggi guna pembangunan bangsa.

3. Nilai menjunjung persatuan dengan mengembangkan sikap toleransi.

Bangsa Indonesia yang terdiri dari banyak sukubangsa, dapat bersatu dalam satu wadah kesatuan berbangsa dan bernegara. Ini adalah berkat sikap dari masyarakat bangsa Indonesia sendiri yang menjunjung persatuan dan kesatuan. Kendatipun mereka berasal dari latar belakang sukubangsa yang memiliki kebudayaan berbeda-beda, akan tetapi mereka sepakat untuk bersatu membentuk bangsa yang besar yakni bangsa Indonesia. Keadaan ini menjadi ciri kepribadian bangsa Indonesia yang memberikan citra pada perwujudan kebudayaan Indonesia dengan budaya persatuannya.Nilai-nilai persatuan dan kesatuan ini ditunjang dengan mengembangkan sikap toleransi. Hal ini telah dibuktikan dalam sejarah yakni dengan dikumandangkan-nya Sumpah Pemuda pada 28 Oktober 1928 yang mengikrarkan Satu Nusa, Satu Bangsa dan satu Bahasa, yaitu Indonesia.

4. Nilai menjunjung tinggi masyarakat dan kegotongroyongan.

Perbedaan-perbedaan pendapat adalah biasa, akan tetapi perbedaan pendapat itu bukan untuk dipertentangkan, melainkan untuk dicapai suatu kesepakatan. Itulah arti musyawarah yang sesuai dengan kepribadian bangsa. Dalam menghadapi masalah-masalah yang menyangkut kehidupan bersama, kita senantiasa menyelesaikan secara bersama-sama pula. Hal ini tercermin dalam ungkapan yang berbunyi 'berat sama dipikul ringan sama dijinjing'. Ungkapan ini mencerminkan nilai-nilai kegotong- royongan bangsa kita yang menjiwai 
persatuan dan kesatuan. Gotong royong dan musyawarah tidak mengenal keistimewaan atau pengecualian bagi orang besar, orang berpangkat maupun orang kaya.

5. Nilai kesetiakawanan.

Kesetiakawanan merupakan modal dasar dalam persatuan dan kesatuan. Kesetiakawanan yang dimaksud adalah kesetiakawanan antar sukubangsa, antar agama maupun antar kelompok atau golongan. Bagi masyarakat yang hidup dengan beraneka ragam sukubangsa, dan agama tindakan kesetiakawanan merupakan kunci bagi selaras dan serasinya hubungan. Kesetiakawanan perlu ditegakkan dalam rangka mewujudkan integrasi nasional. Untuk mencapai integrasi nasional kita harus mampu melepaskan diri dari kepentingan sukubangsa, agama, dan kelompok. Semboyan' sepi ing pamrih rame ing gawe' yang berarti suka menolong dengan tidak menuntut balas harus kita laksanakan pada seluruh warga masyarakat di sekitar kita.

6. Nilai tenggang rasa.

Nilai tenggang rasa yang dimaksud adalah sikap menempatkan diri pada lingkungan sosial dan kesatuan sosial. Sikap ini sangat berguna pada masyarakat yang heterogen seperti Indonesia. Sikap tenggang rasa sangat diperlukan dalam kehidupan di masyarakat, karena adanya berbagai agama, sukubangsa dan latar belakang budaya di Indonesia. Dengan sikap tenggang rasa tersebut segala kehidupan bermasyarakat dijamin dapat selaras dan serasi. Perwujudan sikap tenggang rasa dalam kehidupan masyarakat dengan budaya yang beragam akan sangat membentuk keharmonisan. Perwujudan sikap tenggang rasa tersebut seperti menahan diri, menghormati pendapat orang lain dan sebagainya. Dengan kata lain segala tindakan kita harus berorientasi pada orang di sekitar kita dan tidak mementingkan diri kita sendiri. Dalam ungkapan Jawa yang berbunyi 'aja njiwit nek ora gelem dijiwit' yang berarti jangan mencubit kalau tidak ingin dicubit. Nilai yang terkandung di dalamnya adalah menjaga keselarasan sosial dengan tidak mendahului membuat keributan dengan orang di sekitar kita. Nilai tenggang rasa ini merupakan sarana bagi persatuan dan kesatuan bangsa serta integrasi nasional.

2) Permasalahan yang sering menghambat integrasi nasional yang disebabkan ketertutupan sukubangsa baik lokasi, politik maupun kurangnya pergaulan antar sukubangsa

1. Adanya perbedaan persepsi yang disebabkan perbedaan suku bangsa.

Dalam pergaulan antar sukubangsa di Indonesia, kita masih sering memakai sudut pandang stereotype sukubangsa yang sebenarnya merupakan produk penjajah, guna memecah belah bangsa kita. Penilaian subyektif antara warga satu sukubangsa terhadap sukubangsa yang lain, misalnya orang Batak kasar, orang Madura suka berkelahi, orang Jawa itu lamban, ternyata masih sering mengemuka dalam pergaulan antar suku bangsa. Sehingga 
berbagai pemikiran subyektif tersebut akan sangat menghambat persatuan, kesatuan dan integrasi bangsa.

2. Perbedaan persepsi yang disebabkan perbedaan ekonomi.

Perbedaan ini biasanya akan sangat tajam antara sukubangsa asli dan golongan suku bangsa keturunan seperti Cina, Arab dan lain-lain. Pada umumnya golongan sukubangsa keturunan terutama sukubangsa Cina yang tinggal di kota- kota besar adalah orang-orang yang sukses dalam dunia bisnis. Kesuksesan tersebut menyebabkan timbulnya suatu kesenjangan yang tajam dengan penduduk asli. Lebih menyakitkan apabila warga sukubangsa Cina atau suku bangsa keturunan yang sukses dalam ekonomi sangat egois, sombong dan tidak mampu beradaptasi dengan lingkungan-nya. Akibatnya akan terjadi kecemburuan sosial, perbuatan anarki dan sebagainya terhadap suku bangsa keturunan.

3. Perbedaan persepsi yang disebabkan perbedaan agama.

Indonesia secara resmi mengakui keberadaan dan kehidupan agama- agama resmi, dan hak kemerdekaan memeluk agama sesuai keyakinannya telah diatur dalam Undang Undang Dasar 1945 Pasal 29, Ayat 2. Namun bagi masyarakat majemuk seperti Indonesia hubungan antar umat beragama sering menyulut timbulnya konflik. Timbulnya istilah seperti Kristenisasi dan Islamisasi, misalnya mewujudkan adanya kecurigaan antara umat beragama. Akibatnya hubungan antar umat beragama cenderung tidak harmonis bahkan kadang-kadang dapat terjadi tindakan-tindakan kriminal yang bertentangan dengan hukum dan Pancasila, seperti pengrusakan rumah ibadah agama lain, peculikan atau pembunuhan terhadap penganut agama lain, perbuatan anarkisme, dan isu-isu yang mendiskreditkan penganut agama lain dan seterusnya.

4. Adanya perbedaan persepsi yang disebabkan letak geografis.

Wilayah Indonesia yang terdiri dari beribu-ribu pulau dengan kekayaannya yang melimpah ruah dari Sabang sampai Merauke, dalam kenyataannya sering terjadi konflik. Hal ini disebabkan kesuburan tanah antara daerah satu dengan lainnya berbeda, seperti tanah di Indonesia bagian timur keadaannya relatif tidak subur, dan bahkan ada yang berawa-rawa, misalnya di Irian Jaya (sekarang Papua). Sedangkan keadaan tanah di Indonesia bagian barat mempunyai potensi yang lebih baik dan subur. Keadaan yang demikian itu akan menimbulkan kesulitan dalam pembangunan. Sehingga pembangunan di Indonesia bagian barat akan relative mudah dan lebih murah, sedangkan di Indonesia bagian timur relatif lebih sulit dan lebih mahal. Akibatnya pembangunan di Indonesia bagian timur belum dapat dilaksanakan secara maksimal. Kenyataan yang demikian ini telah menimbulkan kesenjangan di antara penduduk di dua daerah tersebut. Kesenjangan ini makin bertambah tajam dengan adanya anggapan dan persepsi yang salah seperti pembangunan hanya diprioritaskan di Jawa. Keadaan ini akhirnya akan dapat menghambat persatuan dan kesatuan bangsa serta pelaksanaan integrasi nasional. Segala permasalahan yang terkait dengan kebhinekaan atau keragaman suku bangsa tersebut di samping mempunyai potensi-poteni yang negatif, juga mengandung potensi-potensi yang positif. Oleh karena itu masing-masing sukubangsa yang merupakan bagian dari masyarakat Indonesia akan berusaha menyadari dan memahami latar belakang timbulnya konflik-konflik tersebut. 
Selanjutnya kita tidak boleh terlena dalam masalah-masalah yang dapat mengganggu persatuan dan kesatuan bangsa. Untuk itu perlu kita perhatikan dan kita lihat berbagai hal yang dapat mewujudkan persatuan dan kesaatuan serta integrasi bangsa.

\section{Kesimpulan}

Negara Indonesia yang terdiri dari beribu-ribu pulau besar dan kecil, dan dihuni beratusratus sukubangsa diikat oleh satu semboyan yang mampu mempersatukan bangsa. Semboyan itu tidak lain adalah 'BHINNEKA TUNGGAL IKA'. Memantapkan persatuan dan kesatuan bangsa serta mempertahankan integrasi nasional merupakan agenda yang tidak kunjung usai, dalam bentangan waktu yang panjang. Komitmen dan perjuangan untuk membangun Indonesia yang merdeka bersatu berdaulat, adil dan makmur bukan hanya menjadi tugas generasi sekarang, tetapi jauh hari telah dilakukan oleh generasi-generasi terdahulu, dan selanjutnya menjadi tugas generasi-generasi yang akan datang.

\section{Daftar Pustaka}

Siyoto, S., \& Sodik, M. A. (2015). Dasar metodologi penelitian. Literasi Media Publishing.

Jenderal Wiranto. 1999. Memantapkan Persatuan dan Kesatuan Bangsa di Era Reformasi dalam Makalah Sarasehan Kebudayaan Taman Siswa XI.

Sigit Widiyanto, Anto Akhadiyat.1994/1995. Bersatu Kita Teguh Bercerai Kita Runtuh. Jakarta:Depdikbud.

Sudiro, 1974. 45 Tahun Sumpah Pemuda. Jakarta: Penerbit Yayasan Gedung-Gedung Bersejarah.

Yunus Melalatoa, M. 1995. Ensiklopedi Suku Bangsa, dua jilid. Jakarta: Depdikbud. 